\title{
Molecular Characterization of Shiga Toxin-Producing Escherichia coli Isolated from Ruminant and Donkey Raw Milk Samples and Traditional Dairy Products in Iran
}

\author{
Hassan Momtaz, ${ }^{1}$ Rahil Farzan, ${ }^{2}$ Ebrahim Rahimi, ${ }^{3}$ \\ Farhad Safarpoor Dehkordi, ${ }^{2}$ and Negar Souod ${ }^{4}$ \\ ${ }^{1}$ Department of Microbiology, College of Veterinary Medicine, Islamic Azad University, Shahrekord Branch, \\ Shahrekord 166, Iran \\ ${ }^{2}$ Young Researchers Club, Islamic Azad University, Shahrekord Branch, Shahrekord 166, Iran \\ ${ }^{3}$ Department of Food Hygiene, College of Veterinary Medicine, Islamic Azad University, Shahrekord Branch, \\ Shahrekord 166, Iran \\ ${ }^{4}$ Young Researchers Club, Islamic Azad University, Jahrom Branch, Jahrom 74135-355, Iran
}

Correspondence should be addressed to Hassan Momtaz, hamomtaz@iaushk.ac.ir

Received 6 May 2012; Accepted 4 July 2012

Academic Editors: Y.-Y. M. Chen, M. Dunn, V. Fedorenko, and J. L. Romalde

Copyright (C) 2012 Hassan Momtaz et al. This is an open access article distributed under the Creative Commons Attribution License, which permits unrestricted use, distribution, and reproduction in any medium, provided the original work is properly cited.

\begin{abstract}
The aims of the current study were to detect the virulence factors and antibiotic resistance of Shiga toxin-producing E. coli, in animal milk and dairy products in Iran. After E. coli dentification with culture method, PCR assay were developed for detection of pathogenic genes, serotypes and antibiotic resistance genes of E. coli. Results showed that out of 719 samples, $102(14.18 \%)$ were confirmed to be positive for E. coli and out of 102 positive samples, $17.64 \%$ were O26 and $13.72 \%$ were O157 and $1.96 \%$ were O91 and $1.96 \%$ were O145 serotypes. Totally, the prevalence of $s t x 1$ and papA genes were the highest while the prevalence of $s f a S$ and fyuA were the lowest in the positive samples. PCR results showed that tet $A$, tet $B$ were the highest (64.70\%) and $a a c(3)-I V$ were the lowest $(27.45 \%)$ antibiotic resistant genes in E. coli positive samples. Our study indicated that the isolated E. coli trains in these regions had a highest antibiotic resistance to tetracycline $(58.82 \%)$ and the lowest to nitrofurantoin $(3.92 \%)$. tetA gene and E. coli O157 serotype had highest and $a a c(3)-I V$ gene, and E. coli O145 serotype had a lowest frequency rates of antibiotics resistance genes, in the region.
\end{abstract}

\section{Introduction}

Escherichia coli (E. coli) is a gram-negative, rod-shaped, flagellated, nonsporulating, and facultative anaerobic bacterium which belongs to Enterobacteriaceae Family. This bacterium classified into several categories based on its virulence factors such as enterotoxigenic E. coli (ETEC), attaching and effacing E. coli (AEEC), enteropathogenic $E$. coli (EPEC), enterohemorrhagic E. coli (EHEC), and Shiga toxin-producing E. coli (STEC or VTEC) [1-5]. On the other hand, pathogenic E. coli are classified into groups of strains that cause a common disease using common and remarkable assortments of virulence factors that called pathotypes [6].
The Shiga toxin-producing E. coli (STEC) are the causative agents of severe clinical syndromes in humans like HUS. Four of the most important virulence factors of STEC are the two phage-encoded cytotoxins, called Shiga toxin 1 (stx 1$)$ and Shiga toxin $2(s t \times 2)$, the protein intimin (eae), and the plasmid-encoded enterohaemolysin or enterohaemorrhagic E. coli haemolysin (ehly) [7]. Gastrointestinal diseases, food poisoning, and even death in some cases make this microorganism an insidious threat to human health and food safety $[4,8]$. Trough outbreaks in the European Union [9] and several reports of septicemia in human and animals $[10,11]$ up to recent studies in England [12], all of them have doubled the importance of addressing the issue. 
Studies showed that raw animal milk samples and different dairy products are considered the primary reservoir of STEC $[4,13,14]$. Based on our knowledge, in the majority of cases STEC outbreaks were associated with consumption of raw seafood products, traditional dairy products, unpasteurized milk, contaminated food with pollution sources such as feces, contaminated water, contaminated equipments, infected water, and even infected chief, fast-food, contaminated plants' food, and finally raw or even undercooked foods ([15-18]. There are many E. coli serogroups such as O157, O26, O103, O111, O145, O45, O91, O113, O121 and O128 which produce Shiga toxins [16, 17, 19-21].

Reports showed that among the non-O157 STEC, O26 has been the most common serogroup [22]. Other studies indicated that $\mathrm{O} 157, \mathrm{O} 26$, and $\mathrm{O} 111$ serogroups have been responsible for many outbreaks of $\mathrm{HC}$ and HUS cases [1]. Another researches recommended that E. coli O157 is the most commonly implicated in outbreaks while O111, O26, O103, and $\mathrm{O} 145$ serotypes have also been associated with HC and HUS [2].

There are different cultural methods for enrichment and detection of STEC [23]; however none of them guarantee the speed, accuracy, sensitivity, specificity, and safety. On the other hand, many studies were advertising the safety, accuracy, sensitivity, and specificity of molecular methods like polymerase chain reaction (PCR) for detection of STEC $[4,18]$. To the author's knowledge, in the majority of cases, if the treatment was not sufficient, diseases caused by E. coli, in addition to weakening the body immunity and susceptibility to other diseases, it can lead to death. Treatment of diseases caused by this bacterium often requires antimicrobial therapy; however antibiotic-resistant strains of bacteria cause more severe diseases for longer periods of time than their antibiotic-susceptible counterparts. Several studies showed that antibiotic resistance in $E$. coli is increasing in these days [24]. Therefore, identification of resistance genes of bacteria seems to be so essential in reduction of treatment costs.

Therefore, the purpose of the current survey was to study the prevalence of virulence factors and antibiotic resistance properties of Shiga toxin-producing E. coli isolate from bovine, ovine, caprine, buffalo, camel, and donkey raw milk samples and traditional dairy products in Iran.

\section{Materials and Methods}

2.1. Sampling and Detecting E. coli. Overall 424 milk samples were collected: bovine $(n=110)$, caprine $(n=85)$, ovine $(n=98)$, buffalo $(n=52)$, camel $(n=44)$, and donkey $(n=$ 35) raw milk samples were collected from farm bulk tanks and milk collection centers from several geographic regions of Iran, from March 2010 to March 2011. Bovine and buffalo milk samples were collected throughout this time period. Because the lactating periods of ewes, donkeys, and goats in Iran is seasonal (from March through May and September to November of the subsequent year), caprine, donkey, and ovine milk samples were only available through these months within the forementioned time frame. At each site, sampling of milk was performed according to the International Dairy
Federation Guidelines [34]. Samples (100 mL, in sterile glass containers) were transported to the laboratory at ca. $4^{\circ} \mathrm{C}$ within a maximum of 6-12 h after sampling.

For dairy products, 106 samples of soft cheese, 99 soft butter, and 90 soft ice-cream made up of raw milk were purchased from Shiraz, Isfahan, and Shahrekord-three big cities of Iran supermarkets. All of these dairy products were made traditionally and after collection were kept under refrigeration in plastic bags; information about dates of production and of assigned shelf-lives was not presented. Dairy product samples were collected over a period of six months between May and November 2010 and were analyzed on the day of acquisition. Samples were transported under refrigeration $\left(4-6^{\circ} \mathrm{C}\right)$ in thermal boxes containing ice packs and were tested immediately after collection. A $25 \mathrm{~g}$ portion of each sample was blended with $225 \mathrm{~mL}$ of nutrient broth (Merck, Germany) for $2 \mathrm{~min}$ at normal speed, using a Stomacher lab blender and incubated at $37^{\circ} \mathrm{C}$ for $24 \mathrm{~h}$. A $1 \mathrm{~mL}$ sample of the nutrient broth culture was mixed with $9 \mathrm{~mL}$ of MacConkey broth (Merck, Germany) and further incubated at $37^{\circ} \mathrm{C}$ for $24 \mathrm{~h}$. One loop of each tube was streaked on MacConkey agar (Merck, Germany). Four colonies from each plate with typical E. coli morphology were selected and examined by biochemical tests, including hydrogen sulphide, citrate, urease, and indol.

2.2. DNA Isolation. Bacterial strains were overnight grown in trypticase soy agar (TSA-Merck, German) at $37^{\circ} \mathrm{C}$. One colony was suspended in $100 \mu \mathrm{L}$ of sterile distilled water. After boiling the suspension for $13 \mathrm{~min}$, this was followed by freezing and subsequently centrifuged at 14,000 rpm for $15 \mathrm{~min}$ to pellet the cell debris [35]. The supernatant was used as a template for amplification reaction.

2.3. Polymerase Chain Reaction. PCR assays for detection of STEC serotypes, virulence factors, and antibiotic resistance genes in $E$. coli isolated from animal milk samples and traditional dairy products were performed in 3 states as follows.

The PCR assays, specific primer sequences and the predicted size of the amplified products for the different pathogenic gene coding regions including, cnf1, cnf2, stx1, stx2, eaeA, cdtB, papA, sfaS, fyuA, iutA, traT, and hlyA were employed as previously described [36-40]. Strains of E. coli O157:K88ac:H19, CAPM 5933 and E. coli O159:H20, CAPM 6006 were used as positive controls.

Another PCR was performed for detection of E. coli serotypes by application of specific primers shown in Table 1. The PCR reaction was performed in a total volume of $50 \mu \mathrm{L}$ containing $2.5 \mu \mathrm{L}$ of DNA template, $1.5 \mathrm{mM} \mathrm{MgCl}_{2}, 200 \mu \mathrm{M}$ dNTP (Fermentas), $0.5 \mu \mathrm{M}$ of each primers (F \& R), $1.25 \mathrm{U}$ Taq DNA polymerase (Fermentas), and $5 \mu \mathrm{L}$ PCR buffer $10 \mathrm{X}$. Reactions were initiated at 1 cycle $95^{\circ} \mathrm{C}$ for $3 \mathrm{~min}$, followed by 30 cycles of $95^{\circ} \mathrm{C}$ for $20 \mathrm{~s}, 58^{\circ} \mathrm{C}$ for $40 \mathrm{~s}, 72^{\circ} \mathrm{C}$ for $30 \mathrm{~s}$, and a final elongation step at $72^{\circ} \mathrm{C}$ for $8 \mathrm{~min}$, in a DNA thermal cycler for detection of O157, O145, O103, O26, and O111

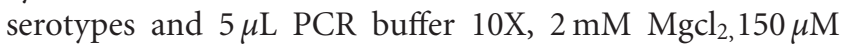
dNTP, $0.75 \mu \mathrm{M}$ of each primers $\mathrm{F} \& \mathrm{R}, 1.5 \mathrm{U}$ Taq DNA 
TABLE 1: Primer sequence for detection of STEC serotypes in animals milk and different traditional dairy products.

\begin{tabular}{|c|c|c|c|c|}
\hline Primer name & Sequence & Size of product (bp) & Target gene & Reference \\
\hline $\begin{array}{l}\text { O26-F } \\
\text { O26-R }\end{array}$ & $\begin{array}{l}\text { CAG AAT GGT TAT GCT ACT GT } \\
\text { CTT ACA TTT GTT TTC GGC ATC }\end{array}$ & 423 & $w z x$ & {$[25]$} \\
\hline $\begin{array}{l}\text { O103-F } \\
\text { O103-R }\end{array}$ & $\begin{array}{l}\text { TTGGAGCGTTAACTGGACCT } \\
\text { GCTCCCGAGCACGTATAAG }\end{array}$ & 321 & $w z x$ & {$[25]$} \\
\hline $\begin{array}{l}\text { O111-F } \\
\text { O111-R }\end{array}$ & $\begin{array}{l}\text { TAG AGA AAT TAT CAA GTT AGT TCC } \\
\text { ATA GTT ATG AAC ATC TTG TTT AGC }\end{array}$ & 406 & $w z x$ & [25] \\
\hline $\begin{array}{l}\text { O145-F } \\
\text { O145-R }\end{array}$ & $\begin{array}{l}\text { CCATCAACAGATTTAGGAGTG } \\
\text { TTTCTACCGCGAATCTATC }\end{array}$ & 609 & $w z x$ & {$[25]$} \\
\hline $\begin{array}{l}\text { O157-F } \\
\text { O157-R }\end{array}$ & $\begin{array}{l}\text { CGG ACA TCC ATG TGA TAT GG } \\
\text { TTG CCT ATG TAC AGC TAA TCC }\end{array}$ & 259 & $w z x$ & [25] \\
\hline $\begin{array}{l}\mathrm{O} 45-\mathrm{F} \\
\mathrm{O} 45-\mathrm{R}\end{array}$ & $\begin{array}{l}\text { CCG GGT TTC GAT TTG TGA AGG TTG } \\
\text { CAC AAC AGC CAC TAC TAG GCA GAA }\end{array}$ & 527 & $w z x 1$ & {$[26]$} \\
\hline $\begin{array}{l}\text { O91-F } \\
\text { O91-R }\end{array}$ & $\begin{array}{l}\text { GCTGACCTTCATGATCTGTTGA } \\
\text { TAATTTAACCCGTAGAATCGCTGC }\end{array}$ & 291 & gnd & {$[27]$} \\
\hline $\begin{array}{l}\text { O113-F } \\
\text { O113-R }\end{array}$ & $\begin{array}{l}\text { GGGTTAGATGGAGCGCTATTGAGA } \\
\text { AGGTCACCCTCTGAATTATGGCAG }\end{array}$ & 771 & $w z x$ & [19] \\
\hline $\begin{array}{l}\text { O121-F } \\
\text { O121-R }\end{array}$ & $\begin{array}{l}\text { TGGCTAGTGGCATTCTGATG } \\
\text { TGATACTTTAGCCGCCCTTG }\end{array}$ & 322 & $w z x$ & {$[28]$} \\
\hline $\begin{array}{l}\text { O128-F } \\
\text { O128-R }\end{array}$ & $\begin{array}{l}\text { GCTTTCTGCCGATATTTGGC } \\
\text { CCGACGGACTGATGCCGGTGATT }\end{array}$ & 289 & galF & [29] \\
\hline
\end{tabular}

polymerase, and finally $3 \mu \mathrm{L}$ DNA template with initiated at 1 cycle $94^{\circ} \mathrm{C}$ for $6 \mathrm{~min}$, followed by 34 cycles of $95^{\circ} \mathrm{C}$ for $50 \mathrm{~s}$, $58^{\circ} \mathrm{C}$ for $70 \mathrm{~s}, 72^{\circ} \mathrm{C}$ for $55 \mathrm{~s}$, and a final elongation step at $72^{\circ} \mathrm{C}$ for $5 \mathrm{~min}$, for detection of $\mathrm{O} 91, \mathrm{O} 128, \mathrm{O} 121, \mathrm{O} 113$, and O45 serotypes of $E$. coli.

The presence of genes associated with resistance to streptomycin, tetracycline, trimethoprim, fluoroquinolone, gentamicin, sulfonamide, cephalothin, ampicillin, and chloramphenicol was determined by PCR, and a set of primers was used for each gene showed in Table 2. PCR reactions were performed in a total volume of $25 \mu \mathrm{L}$, including $2 \mathrm{mM}$ $\mathrm{MgCl}_{2}, 50 \mathrm{mM} \mathrm{KCl}, 10 \mathrm{mM}$ Tris- $\mathrm{HCl}$ (pH 9.0), 0.1\% Triton $\mathrm{X}-100,150 \mu \mathrm{M}$ dNTPs each, $0.4 \mu \mathrm{M}$ primers, $1 \mathrm{U}$ of Taq DNA polymerase, and $4 \mu \mathrm{L}(40-260 \mathrm{ng} / \mu \mathrm{L})$ of DNA. Amplification reactions were carried out using a DNA thermocycler as follows: three min at $95^{\circ} \mathrm{C}, 35$ cycles each consisting of $1 \mathrm{~min}$ at $94^{\circ} \mathrm{C}, 90 \mathrm{~s}$ at $\sim 55^{\circ} \mathrm{C}$ (show in Table 2), $1 \mathrm{~min}$ at $72^{\circ} \mathrm{C}$, and a final extension step of $8 \mathrm{~min}$ at $72^{\circ} \mathrm{C}$.

Finally, a DNA thermocycler (Eppendorf Mastercycler, Eppendorf-Nethel-Hinz GmbH, Hamburg, Germany) was used. The amplified products were visualized by ethidium bromide staining after gel electrophoresis of $10 \mu \mathrm{L}$ of the final reaction mixture in $1.5 \%$ agarose.

2.4. Antimicrobial Susceptibility Testing. Antimicrobial susceptibility tests were performed by the Kirby-Bauer disc diffusion method using Mueller-Hinton agar (HiMedia Laboratories, Mumbai, India, MV1084), according to the Clinical and Laboratory Standards Institute guidelines [41]. After incubating the inoculated plate aerobically at $37^{\circ} \mathrm{C}$ for 18-24 h in an aerobic atmosphere, the susceptibility of the $E$. coli isolates to each antimicrobial agent was measured, and the results were interpreted in accordance with interpretive criteria provided by CLSI (2006). E. coli ATCC 25922 was used as quality control organisms in antimicrobial susceptibility determination.

2.5. Statistical Analysis. Statistical analysis were performed using SPSS/16.0 software for significant relationship between incidences of virulence factors and antibiotics resistance genes of $E$. coli isolated from various animal milk samples and dairy products. Statistical significance was regarded at a $P$ value $<0.05$.

\section{Results}

In the current study, all E. coli colonies were tested by applying PCR method in order to detect $16 \mathrm{~S}$ rRNA gene of bacterium. According to data, out of 424 animal milk samples, $57(13.44 \%)$ and out of 295 traditional dairy products $45(15.25 \%)$ were positive for presence of E. coli (Table 3). Therefore, it was shown that incidences of $E$. coli in different traditional dairy products were higher than animal milk species. Our results showed that bovine $(20.9 \%)$ and soft cheese $(23.58 \%)$ had a highest and camel $(6.81 \%)$ and soft ice cream (10\%) had a lowest rate of E. coli in raw milk and traditional dairy products, respectively (Table 3 ). Statistical analysis of data showed significant differences $(P<0.05)$ between bovine, ovine, caprine, and camel samples as well as donkey and camel milk samples for presence of $E$. coli. On the other hand, significant differences $(P<0.05)$ were observed in soft cheese, soft butter, and ice cream in incidence of this bacterium. It was concluded that the total prevalence of $E$. coli in all samples in Iran was $14.18 \%$ (102 out of 719).

By applying specific primers for detection of STEC serotypes in various samples, it was indicated that out of 102 positive samples for E. coli, 14 (13.72\%), 2 (1.96\%), 
TABLe 2: E. coli-resistant antibiotic genes, primer sequence, and product size.

\begin{tabular}{|c|c|c|c|c|c|}
\hline Antibiotic & Resistant gene & Sequence & Size (bp) & $\begin{array}{c}\text { Annealing } \\
\text { temperature }\left({ }^{\circ} \mathrm{C}\right)\end{array}$ & References \\
\hline Streptomycin & $\operatorname{aadA1}$ & $\begin{array}{l}\text { (F) TATCCAGCTAAGCGCGAACT } \\
\text { (R) ATTTGCCGACTACCTTGGTC }\end{array}$ & 447 & 58 & {$[30]$} \\
\hline Tetracycline & tetA & $\begin{array}{l}\text { (F) GGTTCACTCGAACGACGTCA } \\
\text { (R) CTGTCCGACAAGTTGCATGA }\end{array}$ & 577 & 57 & {$[30]$} \\
\hline Tetracycline & tet $B$ & $\begin{array}{l}\text { (F) CCTCAGCTTCTCAACGCGTG } \\
\text { (R) GCACCTTGCTGATGACTCTT }\end{array}$ & 634 & 56 & {$[30]$} \\
\hline Trimethoprim & $d f r A 1$ & $\begin{array}{l}\text { (F) GGAGTGCCAAAGGTGAACAGC } \\
\text { (R) GAGGCGAAGTCTTGGGTAAAAAC }\end{array}$ & 367 & 45 & {$[31]$} \\
\hline Fluoroquinolone & $q n r$ & $\begin{array}{l}\text { (F) GGGTATGGATATTATTGATAAAG } \\
\text { (R) CTAATCCGGCAGCACTATTTA }\end{array}$ & 670 & 50 & {$[32]$} \\
\hline Gentamicin & $\operatorname{aac}(3)-I V$ & $\begin{array}{l}\text { (F) CTTCAGGATGGCAAGTTGGT } \\
\text { (R) TCATCTCGTTCTCCGCTCAT }\end{array}$ & 286 & 55 & {$[33]$} \\
\hline Sulfonamide & Sul1 & $\begin{array}{l}\text { (F) TTCGGCATTCTGAATCTCAC } \\
\text { (R) ATGATCTAACCCTCGGTCTC }\end{array}$ & 822 & 47 & {$[33]$} \\
\hline Cephalothin & blaSHV & $\begin{array}{l}\text { (F) TCGCCTGTGTATTATCTCCC } \\
\text { (R) CGCAGATAAATCACCACAATG }\end{array}$ & 768 & 52 & {$[33]$} \\
\hline Ampicillin & CITM & $\begin{array}{l}\text { (F) TGGCCAGAACTGACAGGCAAA } \\
\text { (R) TTTCTCCTGAACGTGGCTGGC }\end{array}$ & 462 & 47 & {$[33]$} \\
\hline Chloramphenicol & cat1 & $\begin{array}{l}\text { (F) AGTTGCTCAATGTACCTATAACC } \\
\text { (R) TTGTAATTCATTAAGCATTCTGCC }\end{array}$ & 547 & 55 & {$[33]$} \\
\hline Chloramphenicol & $\mathrm{cmlA}$ & $\begin{array}{l}\text { (F) CCGCCACGGTGTTGTTGTTATC } \\
\text { (R) CACCTTGCCTGCCCATCATTAG }\end{array}$ & 698 & 55 & {$[33]$} \\
\hline
\end{tabular}

$4(3.92 \%), 3(2.94 \%), 3(2.94 \%), 10(9.8 \%), 6$ (5.88\%), 2 $(1.96 \%), 6(5.88 \%)$, and $18(17.64 \%)$ samples were positive for incidences of O157, O145, O128, O121, O113, O111, O103, O91, O45, and O26 serotypes, respectively, while $34(33.33 \%)$ samples have been determined as nondetected serotypes. So the prevalence of $\mathrm{O} 26$ was the highest and both O91 and O145 were the lowest of STEC serotypes (Table 3). In addition, $\mathrm{O} 157(19.29 \%)$ and $\mathrm{O} 145$ (1.75\%) were the highest and lowest serotypes of STEC in raw animal milk samples and O26 (28.88\%) and O91 (0.0\%) were the highest and lowest serotypes of STEC in traditional dairy products, respectively (Table 3 ). Statistical analysis of data indicated significant differences $(P<0.05)$ between total presence of O26, O91, 113, 121, 128, and 145 also O157, O91, and 145 serotypes in samples.

Another part of our study was specialized to determine $E$. coli's virulence genes. Totally stx 1, papA, cnf1, traT, cnf2, and eae were the highest and $s f a S$ was the lowest virulence genes of $E$. coli which were isolated from raw animal milk samples and traditional dairy products (Table 4$)$. Statistical analysis showed significant differences $(P<0.05)$ between stx 1 , papA, and $s f a S$ virulence genes which were isolated from raw animal milk samples and traditional dairy products.

On the other hand, our results revealed that out of 102 E. coli-positive samples, 34 (33.33\%) were non-STEC and 68 $(66.66 \%)$ were diagnosed as STEC serotypes (Table 5). Our results showed that raw bovine milk samples and traditional soft cheese had several virulence genes especially stx 1 and traT, so were the main sources of pathogenic E. coli for human in Iran.
The last part of our study was allotted to antibiotic resistance patterns in $E$. coli that isolated from raw milk samples and traditional dairy products which evaluated by application of PCR for presences of genes associated with resistance to various antibiotics and disc diffusion method. PCR assays were successfully developed for detection of twelve different resistance genes of genomic DNA of E. coli isolates from milk and dairy products.

Our result indicated that overall the prevalence of resistance to tetracycline $($ tet $A+$ tet $B)$ was $64.70 \%$ and both trimethoprim $(d f r A 1)$ and streptomycin $(a a d A 1)$ were $41.17 \%$, respectively (Table 6).

Therefore totally, the prevalence of antimicrobial resistance especially for tetracycline, streptomycin, sulfonamide, chloramphenicol, and finally cephalothin was so high in this survey.

Besides, statistical analysis revealed a statistical significant association $(P<0.05)$ between tet $A$ and tet $B$ genes in dairy production, tetB with aac(3)-IV, qnr, cat1, and $c m l A$ in bovine, ovine, caprine, and buffalo milk samples, aadA1 with $q n r, d f r A 1$, tet $B$, blaSHV, CITM, cat1, and $c m l A$ in soft cheese, butter, and ice cream. Moreover, our results showed that all STEC serotypes which were isolated from raw animal milk samples and traditional dairy products had resistance to more than one antibiotic. Also, based on our data, out of 102 E. coli-positive isolates, all of them were resistant to one or more antimicrobial agent.

Finally, antibiogram tests, beside PCR assays, revealed the highest resistance to tetracycline, penicillin, and enrofloxacin with the frequency rate of $58.82 \%, 46.07 \%$, and $45.09 \%$, 


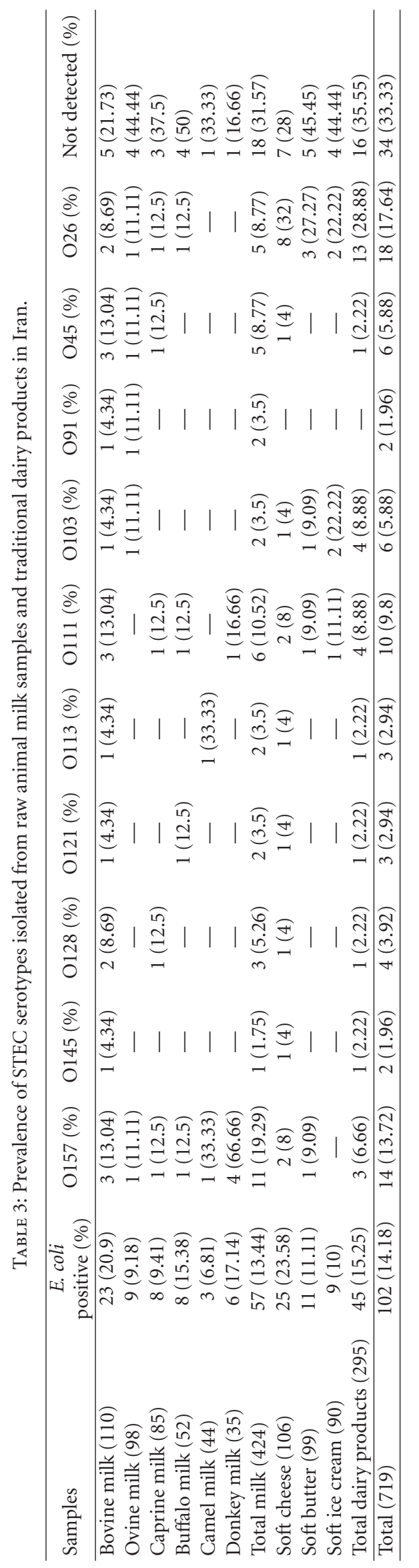




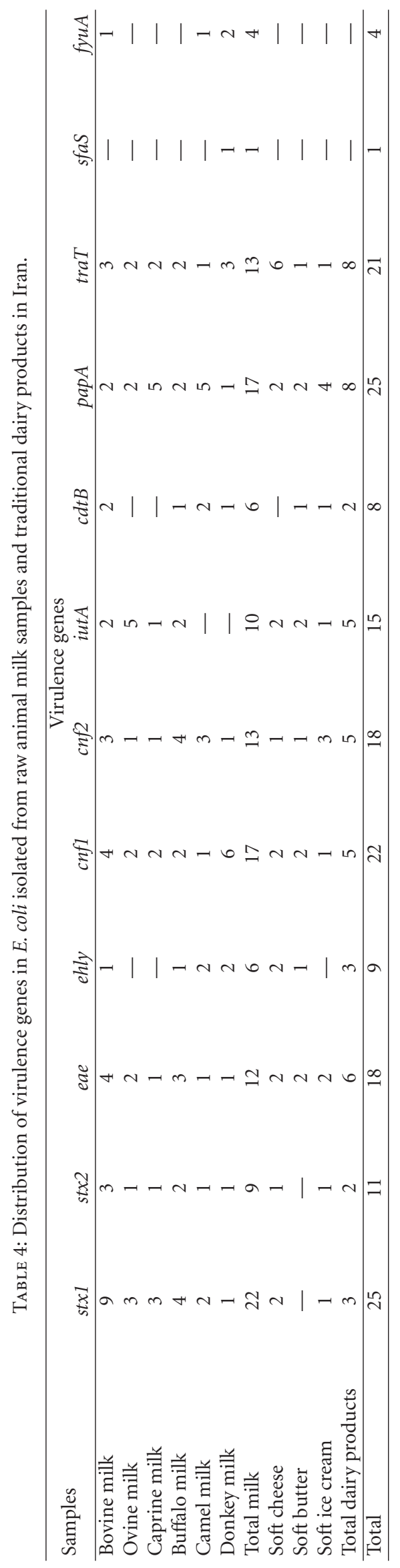


TABle 5: Prevalence of virulence genes in Shiga toxin-producing E. coli serotypes isolated from raw animal milk samples and traditional dairy products in Iran.

\begin{tabular}{|c|c|c|c|}
\hline \multicolumn{2}{|l|}{ Serotype } & \multirow{2}{*}{$\frac{\text { Number of positive samples }(\%)}{34(33.33)}$} & \multirow{2}{*}{$\frac{\text { Virulence gene }(\%)}{-}$} \\
\hline \multirow[b]{3}{*}{ STEC $(68=66.66 \%)$} & & & \\
\hline & EHEC & $14(20.58)$ & stxl, eae, ehly: 14 (100) \\
\hline & AEEC & $54(79.41)$ & $\begin{array}{c}\text { stx1: } 25(46.29) \\
\text { stx2: } 11(20.37) \\
\text { eae: } 18(33.33) \\
\text { stx } 1, \text { eae: } 12(22.22) \\
\text { stx2, eae: } 7(12.96) \\
\text { stx } 1, \text { stx2, eae: } 4(7.4)\end{array}$ \\
\hline
\end{tabular}

TABLE 6: Distribution of antibiotic resistance genes in various serotypes of E. coli isolated from raw animal milk samples and traditional dairy products in Iran.

\begin{tabular}{|c|c|c|c|c|c|c|c|c|c|c|c|}
\hline \multirow{2}{*}{$\begin{array}{l}\text { STEC } \\
\text { serotypes }\end{array}$} & \multicolumn{11}{|c|}{ Antibiotic resistance genes } \\
\hline & $\operatorname{aad} A 1$ & tet $A$ & tetB & $d f r A 1$ & $q n r$ & $\operatorname{aac}(3)-I V$ & sul1 & blaSHV & CITM & cat1 & cmlA \\
\hline O157 (14) & 10 & 7 & 5 & 12 & 14 & 7 & 8 & 7 & 8 & 6 & 4 \\
\hline O26 (18) & 13 & 11 & 4 & 5 & 5 & 8 & 11 & 10 & 9 & 3 & 8 \\
\hline O103 (6) & 1 & 2 & 1 & 2 & 2 & 1 & 2 & 2 & 2 & 1 & - \\
\hline O111 (10) & 3 & 3 & 2 & 7 & 12 & 1 & 4 & 6 & 4 & 4 & 1 \\
\hline O145 (2) & - & - & - & - & - & - & 1 & - & - & - & 1 \\
\hline O45 (6) & 1 & 1 & - & 6 & 1 & - & 1 & 3 & 5 & 1 & - \\
\hline O91 (2) & - & - & 1 & 1 & - & 1 & 1 & - & - & - & - \\
\hline O113 (3) & - & 1 & - & 1 & - & 1 & 1 & 1 & 1 & - & 1 \\
\hline O121 (3) & - & - & 1 & - & - & - & 1 & - & 1 & 1 & - \\
\hline O128 (4) & 1 & 2 & - & 1 & - & - & 1 & 1 & 1 & 1 & 1 \\
\hline $\begin{array}{l}\text { Not detected } \\
(34)\end{array}$ & 13 & 10 & 15 & 7 & 26 & 9 & 12 & 13 & 9 & 6 & 8 \\
\hline Total (102) & $42(41.17)$ & $37(36.27)$ & $29(28.43)$ & $42(41.17)$ & $60(58.82)$ & $28(27.45)$ & $43(42.15)$ & $43(42.15)$ & $40(39.21)$ & $23(22.54)$ & $24(23.52)$ \\
\hline
\end{tabular}

respectively, as well as the lowest resistance to nitrofurantoin and ciprofloxacin with the frequency rate of $3.92 \%$ and $7.84 \%$ (Table 7). On the other hand, in the current situations in Iran, the use of nitrofurantoin and ciprofloxacin due to low antibiotic resistance, can be more effective for treatment of diseases caused by E. coli. This survey indicated the highest antimicrobial resistance in O157, O26 and O111 serotypes. Unfortunately, our results showed that nondetected serotypes had a highest incidence of antibiotics resistance. Besides, bovine had highest and camel had lowest rates of resistance to antibiotics. Statistical analysis showed significant differences $(P<0.05)$ between O157, O26, and nondetected serotypes with O103, 145, 91, 113, 121 and 128 serotypes and between resistance to trimethoprim, streptomycin, lincomycin, penicillin, and tetracycline with nitrofurantoin and ciprofloxacin antibiotics. Totally E. coli antibiotic resistances against common antibiotics which use in veterinary in Iran were so high. Based on Table 6, between these ten serotypes, E. coli O157 and E. coli O145 had a highest and lowest prevalence of antibiotic resistance genes. Results showed that in nondetected serotypes, prevalence of antibiotic resistance genes were so high too.

\section{Discussion}

The present study like the previous studies which introduced ruminants as reservoirs of E. coli O157 [42], for the first time, has been introduced donkeys, camels, and buffaloes as the other sources of E. coli serotypes especially O157. Despite the highest prevalence of E. coli O157 in recent studies [2, 43], our results showed that E. coli O26 had a highest frequency rate in traditional dairy products. On the other hand, our study indicated that in spite of raw animal milk samples, pathogenic E. coli had a highest prevalence in traditional dairy products. Probably using contaminated water in processing traditional dairy products, infected people who produce dairy products, using contaminated equipments, basic infections of dairy sources which are necessary for producing dairy products, and finally lack of public and individual hygiene, are the factors that can be responsible for the higher prevalence of E. coli in traditional dairy products than raw animal milk samples. Only one recent study showed that presence of E. coli O157 in foods may be derived from polluted water [44].

There are several studies which have detected E. coli species in yogurt [45], soft cheeses [46], cheddar cheese [47], 


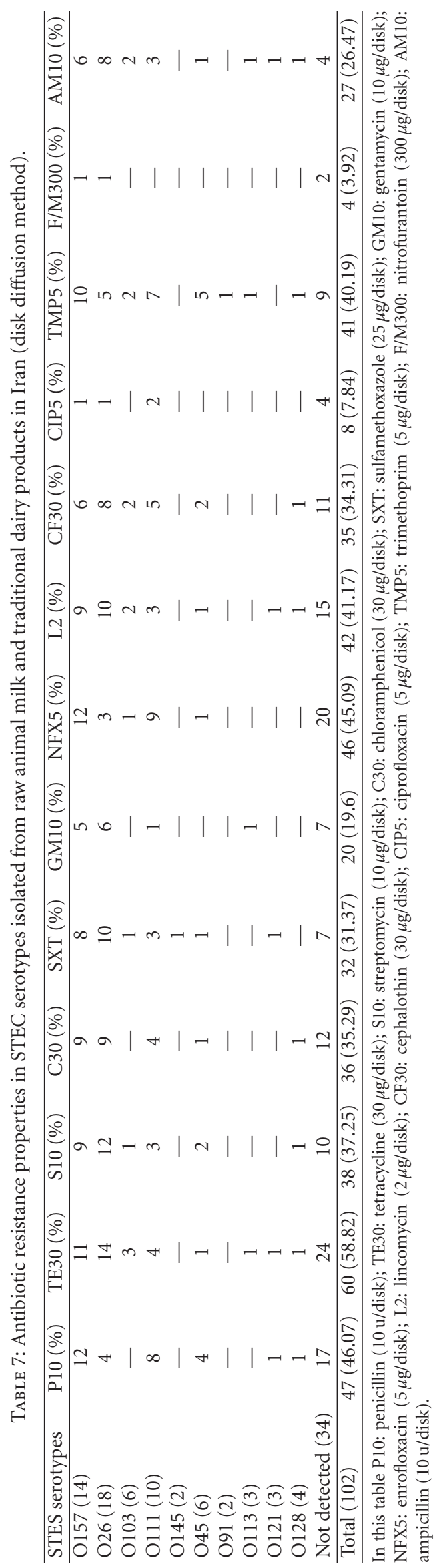


and Feta cheese [48]; however in this survey it is for the first time that we observed that this bacterium can be detected in soft cheese, soft butter, and soft ice cream which were produced in traditional conditions too.

According to Meshref in 2010 from Egypt on cooking butter, $31.7 \%$ of the samples were contaminated by E. coli [49], in which this rate was higher than ours (11.11\%). Another study, performed on dairy products, showed that when the assay was applied with 60 market dairy food samples, one sample each of raw milk, paneer, and ice cream was found to be positive for E. coli O157:H7 [50] that was lower than our study.

Another study in Iran showed that only E. coli O157 subtype was isolated from traditional cheese $(4.2 \%)$, ice cream $(3.33 \%)$, and yoghurt (0\%) [51] that was more limited than our study. The other study in Pantnagar revealed that out of 135 dairy product samples, 11 samples $(8.14 \%)$ were positive for E. coli [52] that was lower than our study $(14.18 \%)$. Recent study from Iran indicated that E. coli O157:H7 can be detected in high rates from white cheese and probiotic cheese [53]. Besides, a 3-year study of E. coli O157:H7 in cattle, camel, sheep, goat, chicken, and beefminced meat in Iran revealed that $1.7 \%$ and $2.1 \%$ of samples were positive for E. coli O157:H7 and E. coli O157:NM, respectively [54]. According to a study in Kerman on raw milk cheese producing, stx genes detected in $6.4 \%$ of the samples, but STEC strains could be isolated in only five of them (4\%) [55]. Another study from Iran showed that about $21.8 \%$ of E. coli isolates from cattle were positive for $e h x A$, stx1, and/or stx2 genes [56], but our study indicated that stx1, cnfl, and eae with incidences of $24.5 \%, 21.56 \%$, and $17.64 \%$ had a highest frequency rate of virulence genes of $E$. coli isolates from raw bovine milk samples.

Therefore, according to the results, the food contamination with animal fecal origin is so obvious in Iran. Based on the other surveys, the presence of E. coli O157 in raw milk and dairy products is proven, however in this investigation we found $\mathrm{O} 26, \mathrm{O} 111, \mathrm{O} 103$, and even $\mathrm{O} 45$ in addition to $\mathrm{O} 157$ as a predominant serotypes of $E$. coli in animal's raw milk and dairy products with the frequency of $17.64 \%$, $9.8 \%, 5.88 \%, 5.88 \%$, and $13.72 \%$, respectively. So in our study E. coli O26 was the predominant serotype, AEEC was the predominant subtype, and papA and stxl were the predominate genes.

Another study in Swiss in 2006 on 432 cheese samples and in 2007 on 364 cheese samples showed $16(3.7 \%)$ and 23 (6.3\%) E. coli-positive samples, respectively, so their results were lower than ours in cheese $(23.58 \%)$ specimens. Further more in this study the investigators found non-O157 STEC strains in 16 samples in which 11 samples based on their $\mathrm{O}$ groups typed into 7 categories (O2, O15, O22, O91, O109, O113, O174), whereas 5 strains were nontypeable. They detect stx 1 in only 1 sample and stx 2 in 15 samples of 16 non-O157 STEC specimens. Furthermore this study showed that 3 STEC strains harbored $E-h l y A$ as a further putative virulence factor and none of the strains tested positive for eae gene [14]. In another study in Irish bovine dairy herds, 85 out of 117 milk filters and 43 out of 120 bulk-tank milk samples were positive for $v t$ genes of E. coli. Out of $v t$-positive samples, 58, 162, 1, 324, and 26 samples were positive for O26, O103, O111, O145, and O157 serotypes, and 10 of these isolates contained at least one of the four virulence genes of $v t 1, v t 2$, eaeA, and $h l y A$ [57].

Recent study in United State reported that EHEC subtype of E. coli was detected in $23 \%$ of strains and eaeA gene was found in $4.2 \%$, and one or both Shiga-like toxin genes (stx1 and $s t \times 2$ ) were positive in bulk-tank milk too. Based on realtime PCR, they proved that 5 samples were contaminated with O157:H7 [58] while our study showed that out of 102 positive samples for E. coli, $13.72 \%$ were EHEC, $17.64 \%$ had eaeA gene, and $35.29 \%$ had both Shiga-like toxin genes.

The prevalence of Shiga toxin in our study (66.66\%) was obviously higher than Lowa $(4.08 \%)$ [59]. Another study on lamb food chain showed that all three virulence genes, eae, stx1, and stx2, were the most prevalent genes in slaughterhouses $(69 \%)$, processing plant $(32 \%)$, and butcheries (9-10\%) [60], but our results indicated that in raw milk and dairy products, stx 1 and $p a p A$ with frequency rate of $24.5 \%$ had a highest prevalence of $E$. coli's virulence genes.

Detection of bacteria in milk samples has some merits like being available and economical. In some geographic places of Iran because of bad climate conditions, bovines, ovine, caprine, and buffaloes are not able to survive, so camels are the main milk supplier for people. So camel's milk hygiene can be essential for human health especially in those especially in that area where the climate is arid and desert. Donkeys' milk samples due to high similarity with human milk and high-sweet components due to high presence of lactose sugar sometimes can be used instead of human milk. Buffaloes' milk hygiene due to high fat and protein contents is very important especially for producing some dairy products.

Studies showed that the antibiotic resistance bacteria which exist in the milk of infected animals can be transmitted to human by the ingestion of unpasteurized milk or dairy products such as cheese, butter, yoghurt, and ice cream. However, the mechanism of spreading antibiotic resistance from food animals to humans remains controversial $[61,62]$.

Our study showed that E. coli O157 was the most prevalent serotype in donkey's milk. Furthermore, this serotype had the highest antibiotic resistance to penicillin and enrofloxacin. To our knowledge, veterinary service-like treatments are very low for donkeys in Iran and unfortunately if a veterinarian wants to apply antibiotical treatments, in most of cases uses penicillin and enrofloxacin for donkeys. Therefore, the high antibiotic resistance in donkeys to these two antibiotics (in our study) may be occurred due to these successive and ectopic treatments, but in bovines the best choices for antibiotic treatment were enrofloxacin, trimethoprim, and tetracycline. So due to the high administration of antibiotics, the prevalence of antibiotic resistance against these antibiotics was so high in bovine's milk samples in the current study. Veterinary interventions and antibiotic administrations are not common in camels in Iran. In most regions of Iran, camel's distribution is so low and reports about the occurrences of diseases in camels usually were low in Iran. Therefore based on our results, it seems logical that 
the prevalence of antibiotics resistance in camel samples was low.

Our results showed that $58.82 \%$ of isolated E. coli from raw milk and traditional dairy products were tetracycline resistant. As well as an other study, substantial numbers of human E. coli isolates were tetracycline resistant [63]. Recent study indicated that $61 \%$ of $E$. coli which isolated from humans, cattle, swine, and food during 1985 to 2000 was susceptible to all 13 antimicrobials tested, while $27 \%$ of them were resistant to tetracycline, 26\% to sulfamethoxazole, $17 \%$ to cephalothin, and $13 \%$ to ampicillin [63]. As the present study indicates, there is a high antibiotic resistance in E. coli which isolated from raw milk and traditional dairy products.

A report from Scotland revealed that the frequency of antibiotic-resistant E. coli was $10.6 \%$ in milk samples and suggested that the prevalence of antibiotic-resistant strains in milk was higher in housed bovines than in outdoor bovines. This study showed that out of 1125 E. coli isolates tested, $22.2 \%$ were antibiotic resistant, and out of these resistant strains, $42.4 \%$ were resistant to more than one antibiotic [64]. Another study in Iran indicated that the resistance of the E. coli strains isolated from traditional cheese, ice cream, and yoghurt to ampicillin and gentamycin was the most common findings (44.4\%), followed by resistance to erythromycin $(33.3 \%)$, amoxicillin $(11.1 \%)$, tetracycline (11.1\%), and nalidixic acid (11.1\%) [51]. Our study showed that two of the most prevalent resistant genes of $E$. coli were tet $A+$ tet $B(64.70 \%)$, and this is similar to previous study that was performed on cow's milk [65].

Unfortunately, indiscriminate prescribing of antibiotics in veterinary is so high and in a report from Netherland $300000 \mathrm{~kg}$ of antibiotics are used annually on veterinary prescription in animals [66]. These high amounts of antibiotics can be kept in animals and lead to antibiotics resistance in bacteria. Then resistance genes of bacteria shedding from milk and meat can be used in humans. So these resistance genes will be causing drug resistance in human too. Our results showed that simultaneous application of culture and PCR can easily be effective in diagnosis of pathogens and their resistance factors especially in food for human consumption.

Our results revealed that (i) using raw milk without pasteurization and milking with unsanitary methods and using traditional dairy products that are produced in unsanitary conditions and probably from unpasteurized milk are the main resources for growth, proliferation, and survival of E. coli and cause several disorders for human. Therefore, vaccinating dairy animals (if necessary), improving methods of milking, checking milking halls in order to detect E. coli especially in the animal feces monthly, fumigating milking halls frequently, observing hygiene during milking, boiling milk, using pasteurized milk for dairy products, keeping dairy products in cool and dry places, away from sunlight, and finally preventing contamination of dairy products with extrinsic factors like insects and dust are the best ways to prevent E. coli infections. (ii) Chloramphenicol is a forbidden antibiotic, and the high antibiotic resistance to drug in our study indicated the irregular and unauthorized use of this antibiotic, in veterinary treatment in Iran. Unfortunately, veterinarians in many fields of veterinary such as large animal internal medicine, poultry, and even aquaculture use this antibiotic as a basic one. Therefore, in a very short period of time, antibiotic resistance will appear. (iii) We recommend PCR method as an accurate, safe, and fast diagnostic one for detection of pathogens in milk and dairy products (iv) due to antibiotic resistance especially in $E$. coli, the veterinarians should pay more attention to prescribing the antibiotics. (v) E. coli virulence genes especially stx1, stx2, eae, cnfl, cnf2, iutA, papA, and finally traT are well distributed in milk and dairy products in Iran. (vi) STEC serotypes and especially AEEC are the predominant strains and O157, and O26 serotypes are the predominant serotypes of bacterium in animal raw milk and traditional dairy products in Iran. (vii) Bovine and camel raw milk and soft cheese and ice cream had a highest and lowest frequency rate of pathogenic E. coli in raw milk and dairy product samples in Iran, respectively. (viii) In order to prevent antibiotic resistance in bacteria, we should apply antibiotics more cautiously in animals, detect resistance genes, and finally use different antibiotics periodically. Our results recommended the use of PCR for detection of antibiotic resistance genes of bacteria as a safe, rapid, and accurate method in laboratories.

\section{Acknowledgments}

The authors would like to thank Dr. E. Tajbakhsh and Mr. M. Momeni at the Biotechnology Research Center of the Islamic Azad University of Shahrekord for their important technical and clinical support. This work was supported by the Islamic Azad University, Shahrekord Branch, Iran, Grant 90/9025.

\section{References}

[1] I. Holko, T. Bisova, Z. Holkova, and V. Kmet, "Virulence markers of Escherichia coli strains isolated from traditional cheeses made from unpasteurised sheep milk in Slovakia," Food Control, vol. 17, no. 5, pp. 393-396, 2006.

[2] H. Karch, P. I. Tarr, and M. Bielaszewska, "Enterohaemorrhagic Escherichia coli in human medicine," International Journal of Medical Microbiology, vol. 295, no. 6-7, pp. 405-418, 2005.

[3] E. Fröhlicher, G. Krause, C. Zweifel, L. Beutin, and R. Stephan, "Characterization of attaching and effacing Escherichia coli (AEEC) isolated from pigs and sheep," BMC Microbiology, vol. 8 , article 144, 2008.

[4] N. Solomakos, A. Govaris, A. S. Angelidis et al., "Occurrence, virulence genes and antibiotic resistance of Escherichia coli O157 isolated from raw bovine, caprine and ovine milk in Greece," Food Microbiology, vol. 26, no. 8, pp. 865-871, 2009.

[5] Q. Wang, X. Ruan, D. Wei et al., "Development of a serogroupspecific multiplex PCR assay to detect a set of Escherichia coli serogroups based on the identification of their O-antigen gene clusters," Molecular and Cellular Probes, vol. 24, no. 5, pp. 286290, 2010.

[6] J. B. Kaper, J. P. Nataro, and H. L. T. Mobley, "Pathogenic Escherichia coli," Nature Reviews Microbiology, vol. 2, no. 2, pp. 123-140, 2004. 
[7] D. Law, "Virulence factors of Escherichia coli O157 and other Shiga toxin- producing E. coli," Journal of Applied Microbiology, vol. 88, no. 5, pp. 729-745, 2000.

[8] J. Meng, M. P. Doyle, T. Zhao, and S. Zhao, "Enterohemorrhagic Escherichia coli," in Food Microbiology: Fundamentals and Frontiers, M. P. Doyle and L. R. Beuchat, Eds., ASM Press, Washington, DC, USA, 3rd edition, 2007.

[9] European Food Safety Authority (EFSA), "The community summary report on trends and sources of zoonoses, zoonotic agents, antimicrobial resistance and foodborne outbreaks in the European Union in 2006," EFSA Journal, vol. 130, pp. 1352, 2007.

[10] J. Harel, J. Fairbrother, C. Forget, C. Desautels, and J. Moore, "Virulence factors associated with F165-positive Escherichia coli strains isolated from piglets and calves," Veterinary Microbiology, vol. 38, no. 1-2, pp. 139-155, 1993.

[11] C. Martin, E. Rousset, and H. De Greve, "Human uropathogenic and bovine septicaemic Escherichia coli strains carry an identical F17-related adhesin," Research in Microbiology, vol. 148, no. 1, pp. 55-64, 1997.

[12] I. A. Gillespie, S. J. O’Brien, G. K. Adak, T. Cheasty, and G. Willshaw, "Foodborne general outbreaks of Shiga toxinproducing Escherichia coli O157 in England and Wales 1992 2002: where are the risks?" Epidemiology and Infection, vol. 133, no. 5, pp. 803-808, 2005.

[13] H. S. Hussein and T. Sakuma, "Invited review: prevalence of Shiga toxin-producing Escherichia coli in dairy cattle and their products," Journal of Dairy Science, vol. 88, no. 2, pp. 450-465, 2005.

[14] R. Stephan, S. Schumacher, S. Corti, G. Krause, J. Danuser, and L. Beutin, "Prevalence and characteristics of Shiga toxinproducing Escherichia coli in Swiss raw milk cheeses collected at producer level," Journal of Dairy Science, vol. 91, no. 7, pp. 2561-2565, 2008.

[15] H. Sanath Kumar, S. K. Otta, I. Karunasagar, and I. Karunasagar, "Detection of Shiga-toxigenic Escherichia coli (STEC) in fresh seafood and meat marketed in Mangalore, India by PCR," Letters in Applied Microbiology, vol. 33, no. 5, pp. 334-338, 2001.

[16] L. Heijnen and G. Medema, "Quantitative detection of E. coli, E. coli $\mathrm{O} 157$ and other shiga toxin producing E. coli in water samples using a culture method combined with realtime PCR," Journal of Water and Health, vol. 4, no. 4, pp. 487498, 2006.

[17] M. C. Erickson and M. P. Doyle, "Food as a vehicle for transmission of Shiga toxin-producing Escherichia coli," Journal of Food Protection, vol. 70, no. 10, pp. 2426-2449, 2007.

[18] J. Madic, N. Vingadassalon, C. P. de Garam et al., "Detection of Shiga toxin-producing Escherichia coli serotypes O26:H11, O103:H2, O111:H8, O145:H28, and O157:H7 in raw-milk cheeses by using multiplex real-time PCR," Applied and Environmental Microbiology, vol. 77, no. 6, pp. 2035-2041, 2011.

[19] C. DebRoy, E. Roberts, J. Kundrat, M. A. Davis, C. E. Briggs, and P. M. Fratamico, "Detection of Escherichia coli Serogroups $\mathrm{O} 26$ and $\mathrm{O} 113$ by PCR Amplification of the $w z x$ and $w z y$ Genes," Applied and Environmental Microbiology, vol. 70, no. 3, pp. 1830-1832, 2004.

[20] C. Jenkins, M. C. Pearce, A. W. Smith et al., "Detection of Escherichia coli serogroups O26, O103, O111 and O145 from bovine faeces using immunomagnetic separation and PCR/DNA probe techniques," Letters in Applied Microbiology, vol. 37, no. 3, pp. 207-212, 2003.
[21] A. Lin, L. Nguyen, T. Lee et al., "Rapid O serogroup identification of the ten most clinically relevant STECs by Luminex microbead-based suspension array," Journal of Microbiological Methods, vol. 87, pp. 105-110, 2011.

[22] Infectious Agents Surveillance Center, National Institute of Infectious Diseases, "The status of enterohemorrhagic Escherichia coli Escherichia coli infection, 1998-March 2000," Infectious Agents Surveillance Reports, vol. 21, pp. 92-93, 2000.

[23] De Boer E and A. E. Heuvelink, "Methods for the detection and isolation of Shiga toxin-producing Escherichia coli.", Symposium Series Society of Applied Microbiology, vol. 88, pp. 133S-143S, 2000.

[24] P. Cortés, V. Blanc, A. Mora et al., "Isolation and characterization of potentially pathogenic antimicrobial-resistant Escherichia coli strains from chicken and pig farms in spain," Applied and Environmental Microbiology, vol. 76, no. 9, pp. 2799-2805, 2010.

[25] B. Possé, L. De Zutter, M. Heyndrickx, and L. Herman, "Metabolic and genetic profiling of clinical O157 and nonO157 Shiga-toxin-producing Escherichia coli," Research in Microbiology, vol. 158, no. 7, pp. 591-599, 2007.

[26] C. DebRoy, P. M. Fratamico, E. Roberts, M. A. Davis, and Y. Liu, "Development of PCR assays targeting genes in O-antigen gene clusters for detection and identification of Escherichia coli $\mathrm{O} 45$ and $\mathrm{O} 55$ serogroups," Applied and Environmental Microbiology, vol. 71, no. 8, pp. 4919-4924, 2005.

[27] S. Perelle, F. Dilasser, J. Grout, and P. Fach, "Identification of the O-antigen biosynthesis genes of Escherichia coli O91 and development of a O91 PCR serotyping test," Journal of Applied Microbiology, vol. 93, no. 5, pp. 758-764, 2002.

[28] P. M. Fratamico, C. E. Briggs, D. Needle, C. Y. Chen, and C. DebRoy, "Sequence of the Escherichia coli O121 O-antigen gene cluster and detection of enterohemorrhagic E. coli O121 by PCR amplification of the wzx and wzy genes," Journal of Clinical Microbiology, vol. 41, no. 7, pp. 3379-3383, 2003.

[29] J. Shao, M. Li, Q. Jia, Y. Lu, and P. G. Wang, "Sequence of Escherichia coli $\mathrm{O} 128$ antigen biosynthesis cluster and functional identification of an $\alpha$-1,2-fucosyltransferase," FEBS Letters, vol. 553, no. 1-2, pp. 99-103, 2003.

[30] L. P. Randall, S. W. Cooles, M. K. Osborn, L. J. V. Piddock, and M. J. Woodward, "Antibiotic resistance genes, integrons and multiple antibiotic resistance in thirty-five serotypes of Salmonella enterica isolated from humans and animals in the UK," Journal of Antimicrobial Chemotherapy, vol. 53, no. 2, pp. 208-216, 2004.

[31] C. S. Toro, M. Farfán, I. Contreras et al., "Genetic analysis of antibiotic-resistance determinants in multidrug-resistant Shigella strains isolated from Chilean children," Epidemiology and Infection, vol. 133, no. 1, pp. 81-86, 2005.

[32] H. Mammeri, M. Van De Loo, L. Poirel, L. MartinezMartinez, and P. Nordmann, "Emergence of plasmidmediated quinolone resistance in Escherichia coli in Europe," Antimicrobial Agents and Chemotherapy, vol. 49, no. 1, pp. 7176, 2005.

[33] T. T. H. Van, J. Chin, T. Chapman, L. T. Tran, and P. J. Coloe, "Safety of raw meat and shellfish in Vietnam: an analysis of Escherichia coli isolations for antibiotic resistance and virulence genes," International Journal of Food Microbiology, vol. 124, no. 3, pp. 217-223, 2008.

[34] International Dairy Federation (IDF), Milk and Milk Products_-Guidance on Methods of Sampling, IDF Standard, Brussels, Belgium, 1995.

[35] U. Reischl, M. T. Youssef, J. Kilwinski et al., "Real-time fluorescence PCR assays for detection and characterization 
of Shiga toxin, intimin, and enterohemolysin genes from Shiga toxin-producing Escherichia coli," Journal of Clinical Microbiology, vol. 40, no. 7, pp. 2555-2565, 2002.

[36] M. J. Brian, M. Frosolono, B. E. Murray et al., "Polymerase chain reaction for diagnosis of enterohemorrhagic Escherichia coli infection and hemolytic-uremic syndrome," Journal of Clinical Microbiology, vol. 30, no. 7, pp. 1801-1806, 1992.

[37] A. E. Heuvelink, N. C. A. J. Van de Kar, J. F. G. M. Meis, L. A. H. Monnens, and W. J. G. Melchers, "Characterization of verocytotoxin-producing Escherichia coli O157 isolates from patients with haemolytic uraemic syndrome in Western Europe," Epidemiology and Infection, vol. 115, no. 1, pp. 1-14, 1995.

[38] M. Blanco, J. E. Blanco, J. Blanco et al., "Polymerase chain reaction for detection in Escherichia coli strains producing cytotoxic necrotizing factor type 1 and type 2 (CNF1 and CNF2)," Journal of Microbiological Methods, vol. 26, no. 1-2, pp. 95-101, 1996.

[39] J. R. Johnson and A. L. Stell, "Extended virulence genotypes of Escherichia coli strains from patients with urosepsis in relation to phylogeny and host compromise," Journal of Infectious Diseases, vol. 181, no. 1, pp. 261-272, 2000.

[40] M. Idress, U. Mussarat, Y. Badshah, R. Qamar, and H. Bokhari, "Virulence factors profile of drug-resistant Escherichia coli isolates from urinary tract infections in Punjab, Pakistan," European Journal of Clinical Microbiology and Infectious Diseases, vol. 29, no. 12, pp. 1533-1537, 2010.

[41] Clinical Laboratory Standards Institute (CLSI), PerFormance Standards for Antimicrobial Disk Susceptibility Tests, Approved Standard-Ninth Edition (M2-A9), Clinical and Laboratory Standards Institute, Wayne, Pa, USA, 2006.

[42] B. Oporto, J. I. Esteban, G. Aduriz, R. A. Juste, and A. Hurtado, "Escherichia coli O157:H7 and non-O157 Shiga toxin-producing E. coli in healthy cattle, sheep and swine herds in Northern Spain," Zoonoses and Public Health, vol. 55, no. 2, pp. 73-81, 2008.

[43] I. Caro, V. M. Fernández-Barata, A. Alonso-Llamazares, and M. R. García-Armesto, "Detection, occurrence, and characterization of Escherichia coli O157:H7 from raw ewe's milk in Spain," Journal of Food Protection, vol. 69, no. 4, pp. 920-924, 2006.

[44] P. Zhu, D. R. Shelton, J. S. Karns et al., "Detection of waterborne E. coli $\mathrm{O} 157$ using the integrating waveguide biosensor," Biosensors and Bioelectronics, vol. 21, no. 4, pp. 678-683, 2005.

[45] A. Govaris, P. Koidis, and K. Papatheodorou, "Behaviour of Escherichia coli O157:H7 in sour milk, cows' milk yogurt and ewes' milk yogurt," Journal of Dairy Research, vol. 69, no. 4, pp. 655-660, 2002.

[46] C. Vernozy-Rozand, C. Mazuy-Cruchaudet, C. Bavai et al., "Growth and survival of Escherichia coli O157:H7 during the manufacture and ripening of raw goat milk lactic cheeses," International Journal of Food Microbiology, vol. 105, no. 1, pp. 83-88, 2005.

[47] J. E. Schlesser, R. Gerdes, S. Ravishankar, K. Madsen, J. Mowbray, and A. Y. L. Teo, "Survival of a five-strain cocktail of Escherichia coli O157:H7 during the 60-day aging period of Cheddar cheese made from unpasteurized milk," Journal of Food Protection, vol. 69, no. 5, pp. 990-998, 2006.

[48] A. Govaris, D. K. Papageorgiou, and K. Papatheodorou, "Behavior of Escherichia coli O157:h7 during the manufacture and ripening of Feta and Telemes cheeses," Journal of Food Protection, vol. 65, no. 4, pp. 609-615, 2002.
[49] A. M. S. Meshref, "Microbiological quality and safety of cooking butter in Beni-Suef governorate-Egypt," African Health Sciences, vol. 10, no. 2, pp. 193-198, 2010.

[50] J. Singh, V. K. Batish, and S. Grover, "A scorpion probe-based real-time PCR assay for detection of E. coli O157:H7 in dairy products," Foodborne Pathogens and Disease, vol. 6, no. 3, pp. 395-400, 2009.

[51] E. Rahimi, S. Shekarchian Chaleshtori, and P. Parsaei, "Prevalence and antimicrobial resistance of Escherichia coli O157 isolated from traditional cheese, ice cream and yoghurt in Iran," African Journal of Microbiology Research, vol. 5, pp. 3706-3710, 2011.

[52] R. Kumar and A. Prasad, "Detection of E. coli and staphylococcus in milk and milk products in and around pantnagar," Veterinary World, vol. 3, pp. 495-496, 2010.

[53] H. K. Darehabi and P. Nikmaram, "Assessment of the growth and survival of Escherichia coli O157:H7 during the manufacture and storage of Iranian white cheese and probiotic cheese," Global Veterinaria, vol. 6, no. 3, pp. 228-232, 2011.

[54] S. Hajian, E. Rahimi, and H. Mommtaz, "A 3-year study of Escherichia coli O157:H7 in cattle, camel, sheep, goat, chicken and beef minced meat," in Proceedings of the International Conference on Food Engineering and Biotechnology (IPCBEE '11), IACSIT Press, Singapoore, 2011.

[55] L. Mansouri-Najand and M. Khalili, "Detection of shiga-like toxigenic Escherichia coli from raw milk cheeses produced in Kerman-Iran," Veterinarski Arhiv, vol. 77, no. 6, pp. 515-522, 2007.

[56] R, G. Mazhaheri Nejad Fard, T. Behzadian Nezhad, Zahraei Salehi, and N. Atash Parvar, "Evaluation of ehxA, stx1, and stx2 virulence gene prevalence in cattle Escherichia coli isolates by multiplex PCR," Archives of Razi Institute, vol. 60, pp. 5566, 2005.

[57] M. J. Lynch, E. M. Fox, L. O’Connor, K. Jordan, and M. Murphy, "Surveillance of verocytotoxigenic Escherichia coli in Irish bovine dairy herds," Zoonoses and Public Health, vol. 59, no. 4, pp. 264-271, 2012.

[58] J. S. Karns, J. S. Van Kessel, B. J. McClusky, and M. L. Perdue, "Incidence of Escherichia coli 0157:H7 and E. coli virulence factors in US bulk tank milk as determined by polymerase chain reaction," Journal of Dairy Science, vol. 90, no. 7, pp. 3212-3219, 2007.

[59] H. W. Moon, L. J. Hoffman, N. A. Cornick, S. L. Booher, and B. T. Bosworth, "Prevalences of some virulence genes among Escherichia coli isolates from swine presented to a diagnostic laboratory in Iowa," Journal of Veterinary Diagnostic Investigation, vol. 11, no. 6, pp. 557-560, 1999.

[60] S. M. Osés, K. Rantsiou, L. Cocolin, I. Jaime, and J. Rovira, "Prevalence and quantification of Shiga-toxin producing Escherichia coli along the lamb food chain by quantitative PCR," International Journal of Food Microbiology, vol. 141, pp. S163-S169, 2010.

[61] O. E. Adeleke, B. A. Adeniyi, and A. A. Akinrinmisi, "Microbiological quality of local soymilk: a public health appraisal," African Journal of Biomedical Research, vol. 3, pp. 89-92, 2000.

[62] A. C. Fluit and F. J. Schmitz, "Resistance integrons and superintegrons," Clinical Microbiology and Infection, vol. 10, no. 4, pp. 272-288, 2004.

[63] C. M. Schroeder, C. Zhao, C. DebRoy et al., "Antimicrobial resistance of Escherichia coli O157 isolated from humans, cattle, swine, and food," Applied and Environmental Microbiology, vol. 68, no. 2, pp. 576-581, 2002.

[64] D. W. Johnston, J. Bruce, and J. Hill, "Incidence of antibioticresistant Escherichia coli in milk produced in the west of 
Scotland," Journal of Applied Bacteriology, vol. 54, no. 1, pp. 77-83, 1983.

[65] A. Skočková, S. Cupáková, R. Karpíšková, and B. Janštová, "Detection of tetracycline resistance genes in Escherichia coli from raw cow's milk," Journal of Microbiology, Biotechnology and Food Sciences, vol. 1, pp. 777-784, 2012.

[66] A. E. Van den Bogaard, "Antimicrobial resistance-relation to human and animal exposure to antibiotics," Journal of Antimicrobial Chemotherapy, vol. 40, no. 3, pp. 453-454, 1997. 

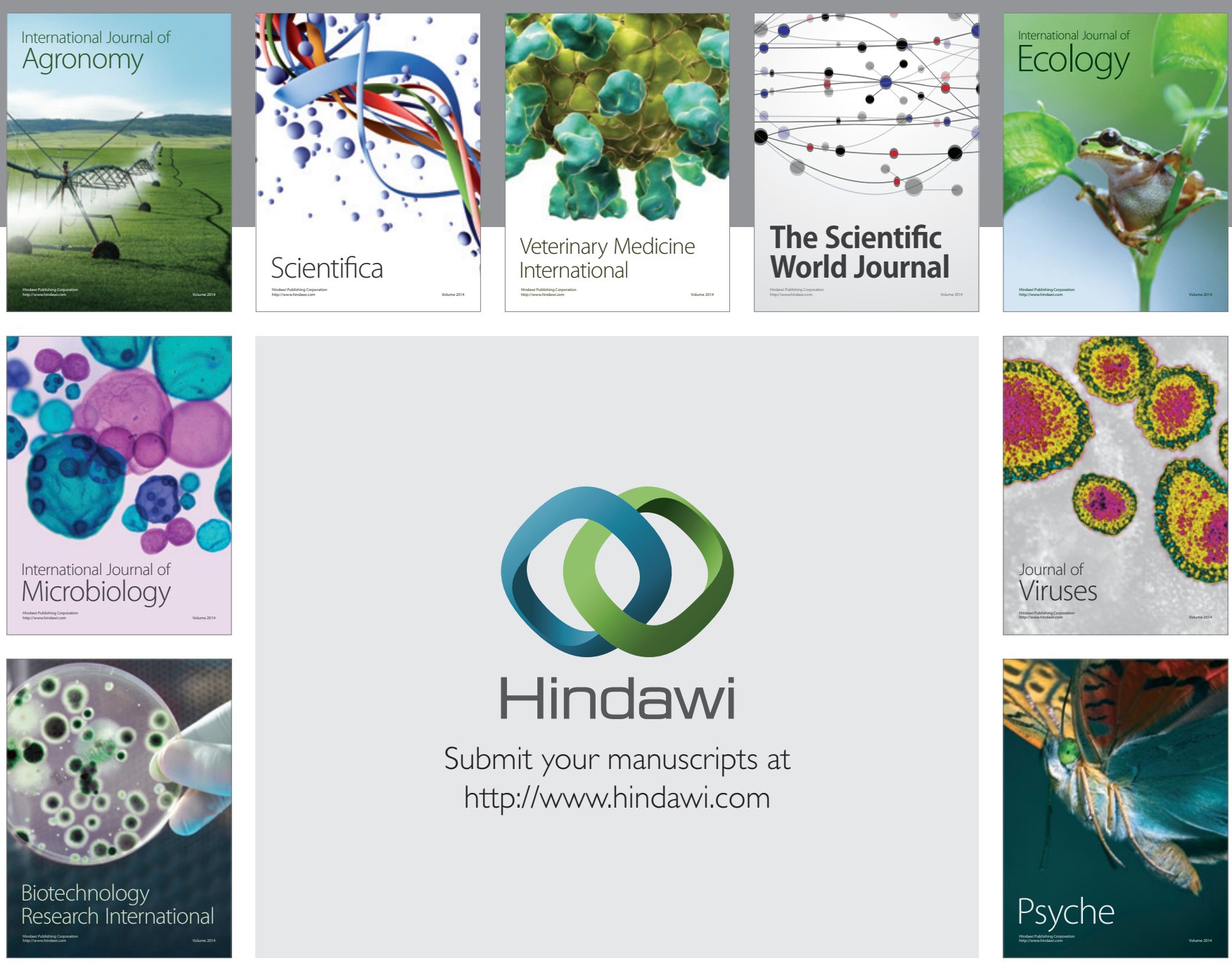

Submit your manuscripts at

http://www.hindawi.com
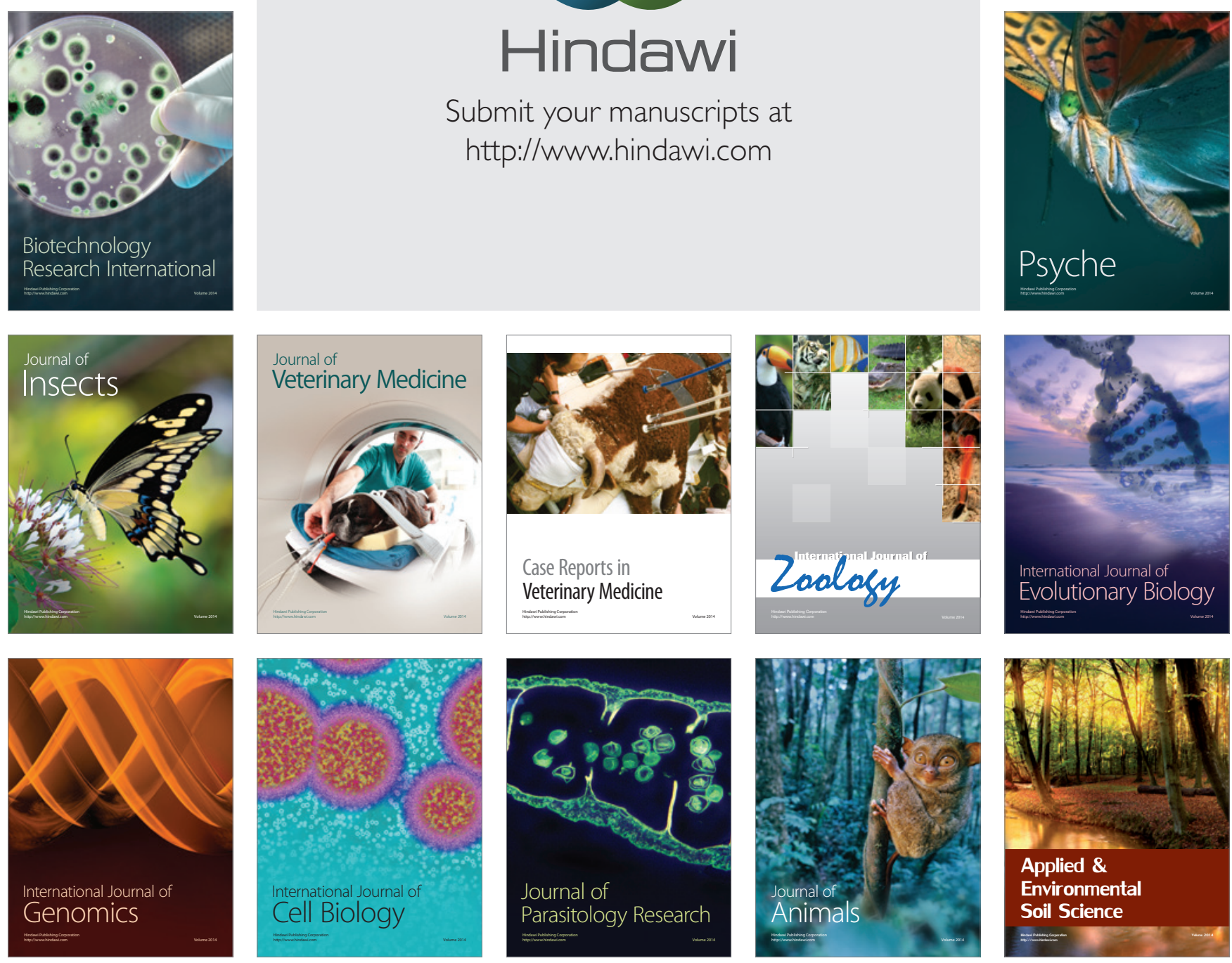